\title{
Leadership styles of the Nursing Directors at the Ministry of Health, Kingdom of Saudi Arabia
}

\author{
Farhan Alshammari* \\ College of Nursing, University of Hail, Hail, Kingdom of Saudi Arabia
}

\begin{abstract}
*Corresponding Author: Dr. Farhan Alshammari, PhD, RN, Dean, College of Nursing, University of Hail, Hail, Kingdom of Saudi Arabia, Tel: 016-535-8362, Fax: 016-531-7027; Email: dr.farhan2015@gmail.com
\end{abstract}

Received Date: December 21, 2017 Accepted Date: January 05, 2018 Published Date: January 12, 2018

Citation: Farhan Alshammari (2018). Leadership styles of the Nursing Directors at the Ministry of Health, Kingdom of Saudi Arabia. POJ Nurs Prac Res 2(1): 1-5.

\begin{abstract}
Background: The need to define the leadership styles of the nursing directors is imperative as it gives the organization an insight of what to achieve. This study determines the leadership styles of the nursing directors in the Ministry of Health, Kingdom of Saudi Arabia. This research aims to assess the association of the age, gender and year of employment of the nursing directors to their identified leadership styles.
\end{abstract}

Methods:This research employed the correlational approach in probing the leadership styles of the nursing directors in the Ministry of Health, Kingdom of Saudi Arabia. There were 22 nursing directors (100\% response rate) participated in the study. The researcher used the Multifactor Leadership Questionnaire, Form 6-S (MLQ- 6S) by Bass and Avolio.

Results: The data suggests that nursing directors employed transactional leadership style in leading their subordinates. It is found out that age has a significant difference in the transactional leadership styles (.037>.05). However, gender and year of employment revealed no significant difference to transformational leadership (.792), transactional leadership (.857), and the laissez-faire (.346).

Conclusion: Demystifying the leadership styles of the nursing directors and its variables can contribute to the understanding of the leadership needs to carry out towards organizational outcomes. The study implies a clear demarcation between an expectation of the leaders and the employees of how leadership and work shall be carried out in the organization.

Keywords: Laissez-Faire, Leadership Styles, Transactional, Transformational, Nursing Directors

\section{Background}

The need to define the leadership styles of the nursing directors is imperative as it gives the organization an insight of what to achieve. A good leader can progressively advance the organization that boosts the employees to do their work and ends up with the desired result. From a nursing perspective, the leadership role is essential in determining substance to support the nurses' work processes and enhance this function in the daily application [1]. However, performing such role requires the nurse leaders to have educational training prior to taking the position, and those already in the post must have capacitybuilding training in planning [2]. As such, the fulfillment of this leadership role in a challenging healthcare organization can impact quality patient care. Today, there is increasing indication that the role of nurse leaders has shifted over the last decades, and move toward a broader area of obligation [2,3]. Indeed, embracing leadership responsibility and aligning with the vision of the organization can enhance the role expectation of the team members within the organization [4].

Studies on leadership styles are mostly focused on the outcomes of leadership styles on the organizational goal. Previous studies have explored on the former, like Lankshear, Kerr, Laschinger, and Wong which they articulated that the achievement of the desired results is credited from the organization and leadership styles of the leaders [5]. In the study of Blakenship, it has pointed out that employees appreciate job satisfaction with transformational and transactional leadership [6]. Likewise, Alshammari supported that leadership outcome have been positively enhancing through transformational leadership [7]. In the local context, leadership studies in the healthcare organization in the Kingdom of Saudi Arabia have exhibited its results to the employees, patients, and the organization. The survey of Aboshaiqah et al., articulated that the importance of

Copyright: (C2018 Farhan Alshammari. This is an open-access article distributed under the terms of the Creative Commons Attribution License, which permits unrestricted use, distribution, and reproduction in any medium, provided the original author and source are credited. 
leadership in the healthcare organization will assure the quality of health care provided, satisfaction, and the performance of the employee [8]. Further, the study of Alshahrani and Baig claimed that in higher transformation style of leadership there is more job satisfaction for nurses [9]. With the previous current literature, there is still limited data in the areas related to leadership styles of the leaders in the Ministry of Health. Indeed, there is more to expand with the emergence of the focus of leadership in the Ministry of Health, Kingdom of Saudi Arabia considering the age, gender and years of employment. Significantly, this study provides an insight into what effective leadership style can be utilized to optimize the performance of the subordinates towards the achievement of the organizational goal. Moreover, this research is intended to bridge the gap in the limitations of the literature of leadership styles employed by the nursing directors. Identifying the leadership styles sets significant steps in contributing towards organizational outcomes. This study determines the leadership styles of the nursing directors using the Multifactor Leadership Questionnaire, Form 6-S (MLQ- 6S). Specifically, it aims to assess the association of the age, gender and year of employment of the nursing directors to their identified leadership styles.

\section{Methods}

This study employed a quantitative approach using correlational design in investigating the leadership styles of the nursing directors at the Kingdom of Saudi Arabia. There were 22 nursing directors (100\% response rate) participated in the study.

This study utilized the Multifactor Leadership Questionnaire, Form 6-S (MLQ- 6S) by Bass and Avolio [10]. It has 21-item questions with 5 Likert scale from $0-4$. The scale points are $0=$ not at all, $1=$ once in a while, 2 = sometimes, 3 = fairly often, and $4=$ frequently, if not always. The questionnaire specifically assesses the leadership style on seven factors comprising the transformational, transactional, and laissez-faire. According to Avolio and Bass, the transformational leadership comprises the factor 1 (Idealized influence) which covers Item 1, 8 and 15 [10]. The factor 2 or inspirational motivation involved Item 2, 9 and 16. Moreover, the factor 3 or intellectual stimulation includes item 3, 10 and 17 while factor 4 or individualized consideration covers the items 4,11 and 18 . For the transactional leadership, it involves factor 5 or contingent reward; this includes item 5, 12 and 19. Lastly, the laissez-faire covers factor 6 or managementby-exception passive (MBEP), and this includes item 6, 13 and 20 , and factor 7or laissez-faire which comprises Items 7, 14 and 21.

To find out the leadership styles of the nursing directors, the researcher added the three rating of the items specified which equivalent to a factor. According to Munaf, the summation of scores of factors $1,2,3$ and 4 is equivalent to the total score of transformational leadership [11]. The total score of transformational leadership will be divided into four (4) to get the composite average score of transformational leadership. On the other hand, the summated score of factor 5 is equal to the total score of transactional leadership to be divided into one (1). Lastly, the score of factor 6 and 7 will be added to get the total score of passive /avoidant behavior divided into two (2) to get the composite average score of passive /avoidant behavior.

Since there is a less nursing director in the Kingdom of Saudi Arabia, the total population sampling technique has been utilized.

This research was with permission by the authorities of the office of nursing directors. It was reviewed and approved by the independent review Board of Hail Region, Kingdom of Saudi Arabia.

\section{Data Collection}

Data gathering was carried out in December 2016 until May of 2017 through a self-administered questionnaire. Before the collection, the researcher provided adequate information, such as the aim of the study, their expected participation, the time required for participation, their right to refuse participation or discontinue their participation for any reason without any consequences to their part. In this study, all of the items have been answered by the respondents.

\section{Data Analysis}

Data analyses were performed using the statistical software, SPSS version 22.0. Descriptive statistics were used to fully describe the demographic characteristics and the leadership styles of the Nursing Directors. One-way ANOVA was used to examine the differences in the age and the multifactor styles of the samples. The T-test was used in examining the leadership styles of the Nursing Directors regarding gender, and years of employment. All statistical analyses were performed at 0.05 level of significance.

\section{Results}

Table 1 shows the demographic profile of the respondents. Most of the nursing directors belonged to $36-40(40.9 \%)$ age group, followed by $30-35(22.7 \%)$. There were $18.2 \%$ belonged to $41-45$ age group, and the least is $46-50(4.5 \%)$ age range. As to gender, male-dominated female with $63.6 \%$ over female having $36.4 \%$. There were 19 nursing directors who have more than 7 years of experience (86.4\%), and below 7 years with $13.63 \%$.

Table 2 shows the rating of the nursing directors as to multifactor leadership styles. It is noted that nursing directors employed transactional in leading their subordinate having an average score of 9.83 followed by transformational with 9.41 and laissezfaire with 7.23 .

Table 3 displays the leadership styles of the nursing directors when age was considered (Table 3). It is noted that transformational leadership and laissez-faire are not significant having an 
F-value of 1.466, and .879 respectively as compared to .05 level of significance. However, the transactional leadership demonstrates significant result is having a lower F-value (.037) compared to .05 significant level of significance.

Table 4 presents the leadership styles of the nursing directors as to gender and years of employment of being a leader. The gender shows no significant relationship to transformational leadership (P-value=.074), transactional leadership (P-value=.006), and laissez-faire (.096) compared to .05 significant level of significance. Moreover, as to years of employment, it proves no significant difference as to leadership styles as evidenced by lower values of transformational leadership (.792), transactional leadership (.857), and laissez-faire (.346) compared to .05 level of significance.

Table 1: Demographic Profiles of the Nursing Directors in the Ministry of Health

\begin{tabular}{|c|c|c|}
\hline Demographics & Frequency & Percentage \\
\hline Age & & 13.6 \\
\hline 25 to 29 & 3 & 22.7 \\
\hline 30 to 35 & 5 & 40.9 \\
\hline 36 to 40 & 9 & 18.2 \\
\hline 41 to 45 & 4 & 4.5 \\
\hline 46 to 50 & 1 & 100.0 \\
\hline Total & 22 & 63.6 \\
\hline Male & 14 & 36.4 \\
\hline Female & 8 & 100.0 \\
\hline Total & 22 & 13.63 \\
\hline Below 7 & & 86.4 \\
\hline Tenure & 3 & 100.0 \\
\hline above 7 & 19 & \\
\hline Total & 22 & \\
\hline
\end{tabular}

Table 2: Multifactor Leadership Styles of the Nursing Directors

\begin{tabular}{|c|c|c|}
\hline Leadership Styles & Factor & Average Score \\
\hline \multirow[t]{4}{*}{ Transformational } & $\begin{array}{l}\text { Factor } 1 \text { Idealized Influence }(1,8 \text { \& 15) } \\
(\mathbf{3 . 2 7} ; \mathbf{2 . 8 2} ; \mathbf{3 . 0 5})\end{array}$ & \multirow[t]{4}{*}{9.41} \\
\hline & $\begin{array}{l}\text { Factor } 2 \text { Inspirational motivation( } 2,9 \& 16) \\
(3.41 ; 3.05 ; 3.32)\end{array}$ & \\
\hline & $\begin{array}{l}\text { Factor } 3 \text { Intellectual stimulation(3, } 10 \& 17) \\
(2.95 ; 3.18 ; 3.14)\end{array}$ & \\
\hline & $\begin{array}{l}\text { Factor } 4 \text { Individualized consideration (Items } 4,11 \text { \& 18) } \\
(3.59 ; \mathbf{2 . 8 6} ; \mathbf{3 . 0 0 )}\end{array}$ & \\
\hline Transactional & $\begin{array}{l}\text { Factor } 5 \text { Contingent reward }(5,12 \text { \& 19) } \\
(\mathbf{3 . 1 4} ; \mathbf{3 . 6 8} ; \mathbf{3 . 0 5})\end{array}$ & 9.83 \\
\hline \multirow[t]{2}{*}{ Laissez Faire } & $\begin{array}{l}\text { Factor } 6 \text { Management-By-Exception Passive (MBEP) }(6,13 \text { \& 20) } \\
\text { (3.55; 1.23; 3.27) }\end{array}$ & \multirow[t]{2}{*}{7.23} \\
\hline & $\begin{array}{l}\text { Laissez-faire }(\mathbf{7}, 14 \& 21) \\
(2.27 ; \mathbf{1 . 5 9} ; \mathbf{2 . 5 5})\end{array}$ & \\
\hline
\end{tabular}

Table 3: Leadership Styles of Nursing Directors as to Age

\begin{tabular}{|l|r|r|}
\hline & \multicolumn{2}{|c|}{ Age } \\
\hline Leadership Styles & \multicolumn{1}{|c|}{ F-value } & Significance level \\
\hline Transformational Leadership & $1.466 \mathrm{NS}$ & .257 \\
\hline Transactional Leadership & $.037 \mathrm{~s}$ & .990 \\
\hline Laissez-faire Leadership & $.879 \mathrm{NS}$ & .471 \\
\hline
\end{tabular}

Citation: Farhan Alshammari (2018). Leadership styles of the Nursing Directors at the Ministry of Health, Kingdom of Saudi Arabia. POJ Nurs Prac Res 2(1): 1-5. 
Table 4: Leadership Styles of Nursing Directors as to Gender and Years of Employment

\begin{tabular}{|l|r|r|r|r|}
\hline \multicolumn{1}{|c|}{ Leadership Style } & \multicolumn{2}{|c|}{ Gender } & \multicolumn{2}{c|}{$\begin{array}{c}\text { Tenure } \\
\text { (Below 7 and above 7) }\end{array}$} \\
\hline & t-value & $\begin{array}{c}\text { Significance level } \\
\text { (2-tailed) }\end{array}$ & t-value & $\begin{array}{c}\text { Significance level } \\
\text { (2-tailed) }\end{array}$ \\
\hline Transformational Leadership & $1.884 \mathrm{NS}$ & .074 & $0.267 \mathrm{NS}$ & .792 \\
\hline Transactional Leadership & $3.057 \mathrm{NS}$ & .006 & $0.183 \mathrm{NS}$ & .857 \\
\hline Laissez-faire Leadership & $1.749 \mathrm{NS}$ & .096 & $0.965 \mathrm{NS}$ & .346 \\
\hline
\end{tabular}

\section{Discussions}

It is remarkable to note that nursing directors of the Ministry of Health $(\mathrm{MoH})$ rated the transactional leadership higher than transformational and laissez-faire. This implies that nursing directors emphasize the grid in their work as a means to efficiently process towards task fulfillment. This present finding is supported by Alshahrani and Baig in pointing out that nurse leader employed transactional leadership as compared to transformational leadership [9]. Further, the findings of Lorber et al., demonstrated that most of the leaders used transactional leadership styles [12]. However, the study finding is contradicted with the study results of Abualrub and Alghamdi, and Moussa et al., who stated that Saudi nurses perceived their nurse leaders as transformational rather than transactional leaders $[13,14]$.

Meanwhile, the finding of this investigation suggests that transactional leadership has the significant association with age. The vast majority of the nursing director in this study belonged to young adult (26-40), and it is indeed expected that they are more on self-directedness. The emergence of the young adult leaders in the healthcare arena contributes to clear roles of the employees of which to utilize towards objective fulfillment. These young adult leaders are mostly striving toward carrying out of the responsibilities designated to them. Although, researchers like Bal et al., Ng and Feldman, Zacher and Bal have settled that age cannot be viewed as a psychological significance construct but impact age-related psychological variable that in turn affect organizational outcomes $[15,16,17]$. In the same vein, the direct relationship between age and leadership may be rare and unstable, and it appears necessary to identify agerelated changes in psychological variables that affect leadership outcomes to comprehend the hidden components amongst age and leadership comportment [18].

This current research found that gender is not significant to the leadership styles of the nursing directors. While it is assumed that leadership style is influenced by the gender role, the gender differences in leadership are swiftly vanishing. Indeed, research after research has demonstrated that leadership between men and women have more similarities than differences and that they are similarly effective. The result as mentioned earlier is related to Paustian-Underdahl, Walker, and Woehr where they concluded that there is no significant difference in leadership effectiveness in the context gender [19]. Moreover, the finding can be corroborated to the study of Cenkci and Özçelik where they found out that gender as a moderating influence is not significantly related to the leadership style and the work engagement of the employee [20].

As to years of employment of being a leader, it is found that there is no significant relationship to leadership styles. The finding implies that years of employment is not a determinant of how effective the leaders will operate the organization. Therefore, the years of employment of leaders in an organization does not automatically bring about an instantaneous transformation in the organizational context. On the other hand, Palm et al. refute the latter in concluding that transformation of the leaders can happen over time [21]. Kotur and Anbazhagan mentioned that there is a transition from one leadership style to another style with experience [22]. Also, with Barbuto et al. they claimed that senior nurses develop leadership skills with experience [23].

Limitation: This present study solely relies on self-reported, perception-based data gathered from currently nursing directors who participated in the survey. No triangulation of findings was adopted, and the study can independently verify the results.

\section{Conclusion}

The study findings are of significance to the present scenario of the organization in the Ministry of Health, Kingdom of Saudi Arabia. Demystifying the leadership styles of the nursing directors and its variables affecting its style can contribute to the understanding of the leadership needs to carry out towards organizational outcomes. The study implies a clear demarcation between an expectation of the leaders and the employees of how leadership and work shall be carried out in the organization.

\section{Acknowledgements}

The author has no funding to report.

\section{Declarations}

Conflict of Interest: The author declares no conflicts of interest.

Citation: Farhan Alshammari (2018). Leadership styles of the Nursing Directors at the Ministry of Health, Kingdom of Saudi Arabia. POJ Nurs Prac Res 2(1): 1-5. 


\section{References}

1. Balsanelli AP, Cunha IC. The work environment and leadership in nursing: an integrative review. Rev Esc Enferm USP. 2014;48(5):938-43.

2. Asamani JA, Kwafo EO, Ansah-Ofei AM. Planning among nurse managers in district hospitals in Ghana. Nurs Manag (Harrow). 2013;20(8):26-31.

3. Hutchinson S, Purcell J. Managing ward managers for roles in HRM in the NHS: overworked and under-resourced. Hum Resour Manage. 2010;20(4):357-374.

4. Reay T, Golden-Biddle K, Germann K. Legitimizing a New Role: Small Wins and Microprocesses of Change. Acad Manage J. 2006;49(5):977-98.

5. Lankshear S, Kerr MS, Spence Laschinger HK, Wong CA. Professional practice leadership roles: the role of organizational power and personal influence in creating a professional practice environment for nurses. Health Care Manage Rev. 2013;38(4):349-60.

6. Blankenship SL. Florida: Nova Southeastern University; 2010. The consequences of transformational leadership and transactional leadership in relationship to job satisfaction and organizational commitment for active duty women serving in the Air Force Medical Service. [DBA Dissertation - Online] Available from: http://nsuworks.nova.edu/hsbe_ etd/12/

7. Alshammari F. Nursing Leadership in the Ministry of Health Hospitals of Saudi Arabia [Online]. Melbourne, Australia: RMIT University; 2014. Available from: https:// researchbank.rmit.edu.au/view/rmit:160740. [Last accessed 2016 Dec 12].

8. Aboshaiqah A, Hamdan-Mansour A, Sherrod D, Alkhaibary A, Alkhaibary S. Nurses' Perception of Managers' Leadership Styles and Its Associated Outcomes. American Journal of Nursing Research. 2014;2(4):57-62.

9. M Alshahrani FM, Baig LA. Effect of Leadership Styles on Job Satisfaction Among Critical Care Nurses in Aseer, Saudi Arabia. J Coll Physicians Surg Pak. 2016;26(5):366-370.

10. Bass BM. Aviolo BJ. Manual for the Multifactor Leadership Questionnaire. Palo Alto, CA: Consulting Psychologists Press; 1990.

11. Munaf S. Teachers' quality performance as a function of management style in higher educational institutions. Working Paper No. 11. [cited 2016 Nov 10]; Available from: http://www.japss.org/upload/WP_no._10mUNAF.pdf

12. Lorber M, Treven S, Mumel D. The Examination of Factors Relating to the Leadership Style of Nursing Leaders in Hospitals. Nase gospodarstvo. 2016;62(1):27-36.
13. Abualrub RF, Alghamdi MG. The impact of leadership styles on nurses' satisfaction and intention to stay among Saudi nurses. J Nurs Manag. 2012;20(5):668-78.

14. Moussa M, Aboshaiqah A, Al Otaibi A. Effect of Nurse's Supervisor's Leadership Style on Nurse's Job Satisfaction. Swift J Nursing Midwifery. 2016;2(2):18-25.

15. Bal PM, de Lange $A H$, Zacher $H$, Van der Heijden BIJM. A lifespan perspective on psychological contracts and their relations with organizational commitment. Eur J Work Organ Psychol. 2013;22(3):279-292.

16. Ng TW, Feldman DC. The relationship of age to ten dimensions of job performance. J Appl Psychol. 2008;93(2):392-423.

17. Zacher $\mathrm{H}, \mathrm{Bal}$ PM. Professor age and research assistant ratings of passive-avoidant and proactive leadership: The role of age-related work concerns and age stereotype. Studies in Higher Education. 2012;37(7):875-896.

18. Schwall AR. Defining age and using age-relevant construct. In: JW Hedge, WC Borman, editors. The Oxford handbook of work and aging. New York: Oxford University Press; 2012. p. 169-186.

19. Paustian-Underdahl SC, Walker LS, Woehr DJ. Gender and Perceptions of Leadership Effectiveness: A Meta-Analysis of Contextual Moderators . J Appl Psychol. 2014;99(6):11291145.

20. Cenkci AT, Özçelik G. Leadership Styles and Subordinate Work Engagement: The Moderating Impact of Leader Gender. Global Business and Management Research: An International Journal. 2015;7(4):8-20.

21. Palm K, Ullström S, Sandahl C. Bergman D. Employee perceptions of managers' leadership over time. Leadersh Health Serv (Bradf Engl). 2015;28(4):266-80.

22. Kotur BR, Anbazhagan S. The Influence of Education and Work-Experience on the Leadership Styles. IOSR-JBM. 2014;16(2):103-110.

23. Barbuto JE, Fritz SM, Matkin GS, Marx DB. Effects of gender, education, and age upon leader's use of influence tactics and full range leadership behaviors. Sex Roles. 2007;56(12):71-83.

Citation: Farhan Alshammari (2018). Leadership styles of the Nursing Directors at the Ministry of Health, Kingdom of Saudi Arabia. POJ Nurs Prac Res 2(1): 1-5. 